\title{
Molecular and morphological characterization of Isthmiophora melis (Schrank, 1788) Luhe, 1909 (Digenea: Echinostomatidae) from American mink (Neovison vison) and European polecat (Mustela putorius) in Lithuania
}

\author{
D. NUGARAITE்* ${ }^{*}$ V. MAŽEIKA, A. PAULAUSKAS
}

Faculty of Natural Sciences of Vytautas Magnus University, Vileikos Str. 8, LT-44404, Kaunas, Lithuania, *E-mail: dovile.nugaraite@vdu.lt

Article info

Received October 12, 2016 Accepted February 15, 2017

\begin{abstract}
Summary
The specimens collected from American mink (Neovison vison) and European polecat (Mustela putorius) in Lithuania were morphologically identified as Isthmiophora melis (Schrank, 1788) Lühe, 1909 and were molecularly characterized through sequencing of partial 18S rDNA, 28S rDNA, ITS15.8S-ITS2 region, and ND1. Relations of $I$. melis to other species of the genus Isthmiophora Lühe 1909 were discussed. According to ITS1 and ND1 sequences the closest species to I. melis is Isthmiophora hortensis (Asada, 1926).
\end{abstract}

Keywords: Isthmiophora melis; Neovison vison; Mustela putorius; NADH dehydrogenase-1; rDNA; Lithuania

\section{Introduction}

Isthmiophora melis (Schrank, 1788) Lühe, 1909 is a frequently found parasite of carnivores and other mammals including human in the Holarctic (Radev et al., 2009).

According to Kostadinova and Gibson (2002), genus Isthmiophora now includes six species: I. melis (Schrank, 1788) Lühe, 1909, I. inermis (Fuhrmann, 1904), I. beaveri (Yamaguti, 1958), I. Iukjanovi (Chertkova, 1971), I. citellicola (Kadenatsii in Skrjabin and Bashkirova, 1956), and I. hortensis (Asada, 1926). The description and identification of species of the genus Isthmiophora are based on measurements of the total body and different organs, their relative size and position e.g. key to species and their descriptions in Kostadinova and Gibson (2002), but these parameters (total size of flukes, relative size of organs and their relative position) are variable and depend on host species (Dönges, 1967, 1968, 1970; Hildebrand et al., 2015) and other factors, such as crowding effects. Because of this problem, to achieve an accurate identification of flukes, we used molecular taxonomy tools.

Previously I. melis was reported (as Euparyphium melis) in Lithua- nia from European polecat (Mustela putorius), European badge (Meles meles), and pine marten (Martes martes) (Kazlauskas \& Prūsaitè, 1976). We have reported $I$. melis in Lithuania from American mink (Neovison vison) and European polecat (Nugaraitè et al., 2014). Kiselienè (1966) reported this species in a mollusc host in Lithuania.

Records of I. melis in the American mink, a species of North American origin, are known both from North America: Canada (Law \& Kennedy, 1932; Gupta, 1962), and United States (Beaver, 1941; Dorney \& Lauerman 1969) and Eurasia: Belarus (Shimalov \& Shimalov, 2001), Germany (Zschille et al., 2004), Italy (Torres et al., 2008), Poland (Hildebrand et al., 2015), and Russia (Kontrimavichus, 1966; Maslennikova, 2010). This species has been reported in the European polecat in Belarus (Shimalov \& Shimalov, 2002), Bulgaria (Kostadinova \& Gibson, 2002), Germany (Klupiec, 2001), Hungary (Sugár \& Matskási, 1978), and Poland (Soltys, 1962).

The first intermediate host of $I$. melis is the pulmonate freshwater snail Lymnaea stagnalis (Linnaeus, 1758) in Europe (Dönges, 1964, Radev et al., 2009). Stagnicola emarginata (Say, 1821) is the first intermediate host in North America (Beaver, 1941). The

\footnotetext{
* - corresponding author
} 
second intermediate hosts are amphibians and freshwater fishes (Dönges, 1964; Radev et al., 2009; Sokolov et al., 2012).

The aim of this study was to identify and characterize the flukes of the genus Isthmiophora from American mink and European polecat collected in Lithuania using morphological and molecular data.

\section{Material and Methods}

Forty American minks and 22 European polecats were collected/hunted in different parts of Lithuania between 2013 and 2015 (Fig. 1). All carcasses were stored at $-20^{\circ} \mathrm{C}$ until examination. Adult individuals of $I$. melis were found in the small intestine of American minks and European polecats using the method of total helminthological dissection of individual organs (Ivashkin et al., 1971).

Parasites were collected and stored in $70 \%$ ethanol until studied. Flukes from six American minks and nine European polecats, 2 - 4

\section{Molecular identification and characterization}

Genomic DNA was extracted from individual ethanol-fixed specimens using the guanidine method described by Tkach and Pawlowski (1999).

Internal transcribed spacer region (ITS1-5.8S-ITS2) and the fragment of mitochondrial nicotinamide adenine dinucleotide dehydrogenase subunit 1 (ND1) gene were amplified using primers BD1, BD2 and NDJ11, NDJ2a respectively (Kostadinova et al., 2003). The polymerase chain reaction (PCR) was performed in a total volume of $20 \mu \mathrm{l}: 2 \mu \mathrm{l} 10 \times$ PCR buffer, $0.64 \mu \mathrm{l}$ dNTPs mixture

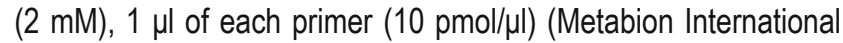
AG, Germany), $0.1 \mu \mathrm{l} \mathrm{Taq}$ polymerase $(5 \mathrm{U} / \mu \mathrm{l}), 1.6 \mu \mathrm{MgCl}_{2}(25$ $\mathrm{mM}$ ) (Thermo Fisher Scientific, Lithuania), $9.66 \mu$ distilled water, and $4 \mu$ template DNA using Eppendorf Thermal cycler Mastercycler personal with the following parameters: initial denaturation at $95{ }^{\circ} \mathrm{C}$ for $1 \mathrm{~min}, 35$ cycles of $96{ }^{\circ} \mathrm{C}$ for $30 \mathrm{~s}\left(94^{\circ} \mathrm{C}\right.$ for ND1)

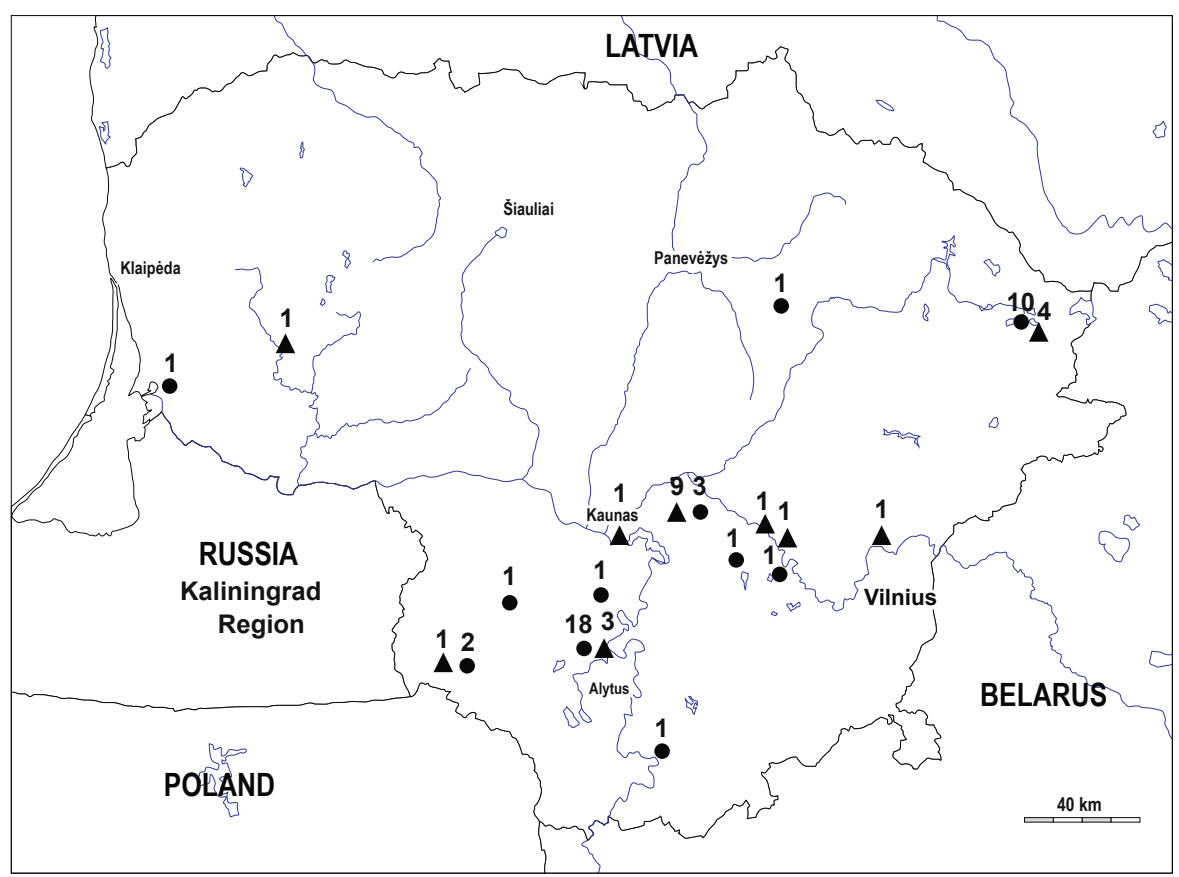

Fig. 1. Collection sites of $N$. vison $(\bullet)$ and M. putorius $(\boldsymbol{\Lambda})$ in Lithuania. The numbers on the map indicate the numbers of collected animals.

worms from each host (in total 36 specimens) were processed for morphological studies following standard procedures of temporary (in glycerine) and permanent (in Canada balsam) preparations (Ivashkin et al., 1971). Measurements (in micrometers) were taken from temporary preparations. First we provide measurements of fluke specimens from American mink and then in square brackets of those from European polecat in our description. The average of the measurements is provided in parentheses. Parasites were measured using a Motic BA400 Tension microscope. The morphological identification was based on the keys provided by Kozlov (1977) and Kostadinova and Gibson (2002). The systematics of the family Echinostomatidae and names of genera are used according to Tkach et al. (2016). (denaturation), $54{ }^{\circ} \mathrm{C}$ for $1 \mathrm{~min}\left(48{ }^{\circ} \mathrm{C}\right.$ for $20 \mathrm{~s}$ for ND1) (primers annealing), $72{ }^{\circ} \mathrm{C}$ for $1 \mathrm{~min}$ (45 s for ND1) (extension), and $7 \mathrm{~min}$ final extension hold at $72{ }^{\circ} \mathrm{C}$.

A fragment of the $18 \mathrm{~S}$ rRNA gene was amplified using WormA, WormB primers (Littlewood \& Olson 2001). The total PCR volume was $25 \mu \mathrm{l}$, which contained $12.5 \mu \mathrm{l}$ 2X PCR Master Mix (Thermo Fisher Scientific, Lithuania), $1 \mu \mathrm{l}$ of each primer (10 pmol/ $\mu \mathrm{l})$, $7.5 \mu$ distilled water, and $3 \mu$ of template DNA. A fragment of the 28S rRNA gene was amplified with digl2, L0 primers (Tkach et al., 2000). The total PCR volume was $15 \mu$, which contained $7.5 \mu \mathrm{l}$ 2X PCR Master Mix (Thermo Fisher Scientific, Lithuania), $0.3 \mu \mathrm{l}$ of each primer ( $10 \mathrm{pmol} / \mu \mathrm{l}), 4.9 \mu \mathrm{l}$ distilled water, and $2 \mu \mathrm{l}$ of template DNA. The amplification of the $18 \mathrm{~S}$ rRNA gene was carried out 
in the thermocycler programmed as follows: initial denaturation at $94{ }^{\circ} \mathrm{C}$ for $3 \mathrm{~min}, 40$ cycles of $94^{\circ} \mathrm{C}$ for $30 \mathrm{~s}, 56^{\circ} \mathrm{C}$ for $30 \mathrm{~s}, 72^{\circ} \mathrm{C}$ for $2 \mathrm{~min}$, and final extension step of $72^{\circ} \mathrm{C}$ for 7 minutes. Amplification conditions for the 28S rRNA gene were the same as for the 18S rRNA gene, except for the annealing temperature $\left(50^{\circ} \mathrm{C}\right)$. Amplicons were separated by horizontal electrophoresis in $1.5 \%$ agarose gels (Thermo Fisher Scientific, Lithuania). The bands were visualized and digitally photographed under UV-light using a transilluminator E.A.S.Y 442 K (Herolab, Wiesloch, Germany). Fragments were sized using Gene Ruler ${ }^{\mathrm{TM}} 100$ bp Plius Ladder (Thermo Fisher Scientific, Lithuania). The amplified fragments were purified using a GeneJet ${ }^{\mathrm{TM}}$ Gel Extraction Kit (Thermo Fisher Scientific, Lithuania) according to the manufacturer's manual.

The PCR products were sequenced in one direction on an $A B I$ PRISM $^{\circledR} 377$ DNA Sequencer. Genes coding for $18 \mathrm{~S}$ and $28 \mathrm{~S}$ rRNA, and ND1 were sequenced from one fluke specimen collected from European polecat. Flukes from nine European polecats and five American minks, two worms from each host (in total 28 specimens) were taken and, after the corresponding procedures, the partial ITS1-5.8S-ITS2 region was sequenced.

The obtained sequences were deposited in GenBank under the following accession numbers: KR092369, KR092370, KR136354, and KU516829.

\section{Data analysis}

The sequencing data was processed using MEGA 6.0 software (Tamura et al., 2013). Nucleotide sequences of ITS1-5.8S-ITS2 (697 bp), 18S rDNA (700 bp), 28S rDNA (701 bp), and ND1 (447 bp) were compared with sequences deposited in the GenBank database (NCBI: The National Center for Biotechnology Information), using the BLAST search.

To estimate the phylogenetic relationships, the nucleotide sequence of the ITS1 and the ND1 gene were aligned with sequences taken from GenBank using the CLUSTAL W algorithm (Thompson et al., 1994) implemented in MEGA.

The phylogenetic trees were generated using maximum likelihood $(\mathrm{ML})$ and Bayesian inference $(\mathrm{BI})$ analyses. Echinostoma revolutum (Froelich, 1802) Dietz, 1909 (Acc. No. GQ463130 for ITS1 and AF026287 for ND1) served as an out-group. The best fit substitution models for the ITS1, and the ND1 datasets were found based on the Bayesian Information Criterion (BIC) and the Akaike Information Criterion (AIC) estimated with MEGA. The ML analysis with bootstrap values based on 1,000 resamples was performed computed by MEGA, while the $\mathrm{BI}$ analysis was generated with $\mathrm{Mr}$ Bayes v.3.2.5 software (Ronquist et al., 2012) using the same (K2 + G for ITS1 and HKY for ND1) best fit substitution model with the following parameters: Iset $n s t=2$, rates = gamma/equal for ITS1 and ND1 respectively. The BI analysis was carried out with two runs over 100,000 generations, each including four simultaneous MCMC chains sampling every 100th tree. The number of generations was sufficient, because the standard deviation was lower than 0.01 at the end of the run. The results of the first $25 \%$ trees were discarded as "burn-in" and all retained trees were used to calculate Bayesian posterior probabilities of each node.

\section{Results}

Thirty of 40 American minks (mean abundance $(A)=31.6$; prevalence $(P)=75 \%)$ and 21 of 22 European polecats $(A=348.6 ; P=$ $95 \%$ ) were infected with flukes morphologically identified as /sthmiophora melis. Totally 8,934 individuals of $I$. melis in American mink (1264) and European polecats (7670) were found.

Description of Isthmiophora melis (Schrank, 1788) Luhe, 1909 from American mink and European polecat (Fig. 2)

Body elongate. Maximum width at level of the ventral sucker or just after it. Body length 6,329 - 9,460 (7,864) $[5,734-9,251$ $(7,644)]$; width $1,089-1,511(1,362)[1,094-1,544(1,300)]$. Forebody $1,103-1,440(1,304)[972-1,555(1,252)], 13.4-20.8 \%$ $(16.7 \%)$ [12.6 - $20.4 \%(16.5 \%)]$ of body length. Tegument of anterior part of body armed with small spines.

Head collar (Fig. 2) reniform, small, 215 - 287×389 - 518 (250×473) [216 - 288×419 - $508(248 \times 464)]$; ventral ridge poorly developed. Collar spines 27 , blunt-pointed. Four angle spines on each ventral lappet ( 2 dorsal and 2 ventral), longer than marginal spines, $59-83 \times 13-20(68 \times 16)[56-108 \times 10-23(76 \times 16)]$. Lateral spines in single row, $51-73 \times 11-19(61 \times 14)[46-85 \times 10$ $-18(60 \times 13)]$. Dorsal spines in double row; oral spines $55-85 \times 10$ - $17(67 \times 13)[50-86 \times 10-19(67 \times 14)]$, slightly longer than aboral, $49-72 \times 10-18(59 \times 13)$ [48 - 78×10 - $19(63 \times 13)]$.

Oral sucker almost spherical, $235-297 \times 228-317(272 \times 271)$ [233 - $345 \times 227-319(265 \times 268)]$. Ventral sucker distinctly larger than oral, located in first quarter of body, $788-995 \times 752-929$ (897×845) $[717$ - 977×654 - $993(862 \times 817)]$. Prepharynx short, $20-87(63)[18-85(50)]$.

Pharynx muscular, elongate-oval, $195-279 \times 159-258(251 \times 199)$ [218 - 269×174 - $247(251 \times 206)]$. Oesophagus $300-390$ (350) [311 - 385 (345)]. Intestinal bifurcation just before ventral sucker. Testes tandem, large, contiguous, smooth or with somewhat irregular margins; anterior testis pre-equatorial, $517-869 \times 564-888$ $(680 \times 693)$ [ $408-851 \times 418-943(648 \times 689)$; posterior testis usually equatorial, elongate-oval, 649 - 1,152×390 - $643(901 \times 553)$ [598 - 1,327×377 - $689(896 \times 541)]$. Post-testicular region 2,202 $4,019(3,071)[2,055-3,885(3,035)]$ long, $33.9-44.2 \%(38.5 \%)$ $[32.1-47.2 \%(39.1 \%)]$ of body length.

Cirrus-sac elongate-oval, 818 - 955×301 - $414(898 \times 346)[717$ $914 \times 294-377(839 \times 339)]$, reaching back dorsally from intestinal bifurcation to middle of ventral sucker dorsally, or near to posterior margin, rarely cirrus-sac located between intestinal bifurcation and ventral sucker. Cirrus long, tubular, armed with spines. Genital pore median, just posterior to intestinal bifurcation.

Ovary spherical, entire, dextral, near anterior testis, $243-400 \times$ 231 - $398(319 \times 310)$ [240 - 381×244 - $400(319 \times 313)]$ in diameter. Distance from ventral sucker to ovary $299-639$ (516) [268 - 


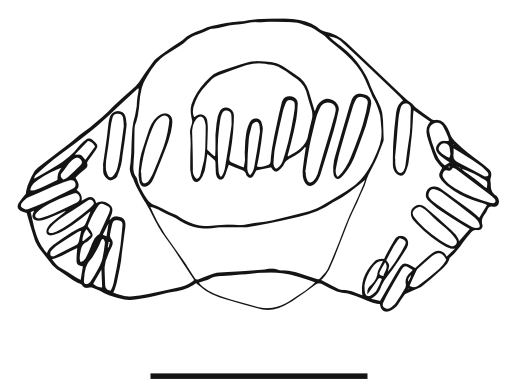

A

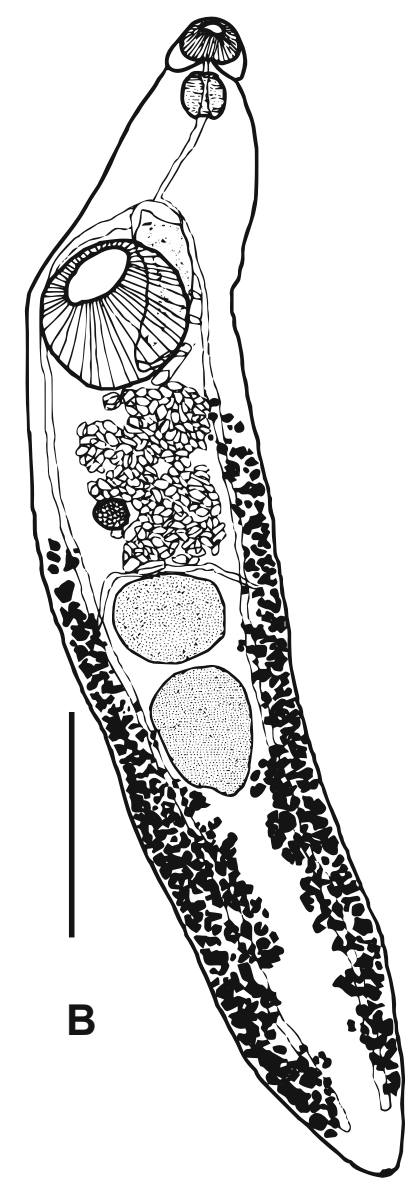

Fig. 2. Isthmiophora melis (Schrank, 1788) Luhe, 1909. A. Head collar. B. Entire worm. Scale-bar: A, 250 m; B, 1 mm.

766 (469)]; the distance as a proportion of body length $3.2-6.5 \%$ (4.9\%) [3.5 - 6.1\% (4.9\%)]. Mehlis' gland strongly developed, median, immediately pretesticular, transversely oval, $240-379 \times 262-$ $540(307 \times 453)[209-388 \times 402-570(322 \times 483)]$. Uterus short, with few intercaecal loops between ovary and ventral sucker. Metraterm muscular, usually as long as cirrus-sac. Eggs not numerous, $126-$ 153×73 - $94(136 \times 86)$ [104 - 157×70 - $99(133 \times 85)]$. Vitellarium follicular; in 2 lateral fields between posterior level of ventral sucker and ovary; almost reaching posterior extremity of body; fields confluent in post-testicular region. Excretory pore subterminal.

\section{Molecular analysis}

Sequences of the PCR products were blasted against the sequences in GenBank.

The alignment of the partial $18 \mathrm{~S}$ rDNA sequence (700 bp) (KR092369) showed $100 \%$ similarity with I. melis (KT359582) (host: Apodemus agrarius (Pallas, 1771); country: Poland) and $99 \%$ similarity with I. melis (AY222131) (host: Nyctereutes procyonoides (Gray, 1834); country: Ukraine) and I. hortensis (AB189982) (host: Procyon lotor (Linnaeus, 1758); country: Japan). The tested sequence differs by one nucleotide from I. melis
(AY222131) and by two nucleotides from I. hortensis (AB189982). A 701 bp fragment sequence of the $28 \mathrm{~S} \mathrm{rDNA}$ (KR092370) showed $100 \%$ similarity with I. melis (KT359583; AF151941), and I. hortensis (AB189982).

The partial sequences of ITS1-5.8S-ITS2 regions (697 bp length) from all 28 fluke specimens were completely identical. The sequence (KR136354) shared a $100 \%$ similarity with I. melis (KT359584), 99 \% similarity with I. hortensis (AB189982; U58101), and only $95 \%$ matches with I. melis (AY168932) which was detected in molluscs (Planorbis sp.) in the United Kingdom. The sequence of I. melis (KR136354) from Lithuania differs by three (AB189982) and nine (U58101) nucleotides from I. hortensis, including three insertions/deletions and two nucleotides which were not identified precisely, and 37 nucleotides including three insertions/deletions from I. melis (AY168932) sequences.

Comparison of the 5.8S rRNA gene with all sequences in GenBank showed $100 \%$ matches with several dozens of trematode sequences, while comparison of the ITS1 sequence of $410 \mathrm{bp}$ length shared high similarity with I. melis (100\% (KT359584)), I. hortensis (99\% (AB189982); $98 \%$ (U58101)) and only $92 \%$ with the I. melis (AY168932) sequence. 
The ITS2 fragment of 125 bp shared $100 \%$ similarity with I. melis (KT359584), I. hortensis (AB189982; U58101), and also $98 \%$ similarity with sequences of $I$. melis (AY168932) and nine other sequences of flukes of Petasiger, Baschkirovitrema, and Cathaemasia genera (Petasiger sp. GC-2015 isolate PH2 - KM972995, Petasiger sp. GC-2015 isolate PH1 - KM972994, Petasiger phalacrocoracis isolate CK1 - KJ720683, P. phalacrocoracis AY245709, Petasiger radiatum isolate KM7 - KM973000, P. radiatum - AY245708, Baschkirovitrema sp. TRG-2012 - JX570738, C. hians - AY761146, and P. radiatum isolate KM5 - KM972998). These results show that the ITS2 fragment is unsuitable for species identification.

The partial sequence of nicotinamide adenine dinucleotide dehydrogenase subunit 1 (ND1) gene (447 bp) (KU516829) shared 91 \% (KR062182) (host: dog; country: China), 90 \% (AF025835) (Korea), and $87 \%$ (AB189981) (host: $P$. lotor, country: Japan) similarity with $I$. hortensis, and only $72 \%$ similarity with I. melis (AY168948) (host: Planorbis sp.; country: United Kingdom). I. melis from Lithuania (KU516829) differs by 41 (KR062182), 43 (AF025835), and 57 (AB189981) nucleotides from I. hortensis, and 126 nucleotides from I. melis (AY168948).

Phylogenetic analysis

Both (ML and BI) analyses based on the ITS1 and ND1 gene dataset exhibited identical tree topologies, therefore only the $\mathrm{ML}$ tree with the bootstrap values and posterior probabilities $(\mathrm{BI})$ is presented (Fig. 3).

The phylogenetic analysis based on the ITS1 (Fig. $3 \mathrm{~A}$ ) showed that I. melis (KR136354) from Lithuania is genetically close related with I. melis (KT359584) from Poland and forms a sister group with genetically close related I. hortensis (AB189982) from Japan and I. hortensis (U58101) collected from East Asia. But, I. melis (AY168932) collected from molluscs in the United Kingdom formed a single clade with four sequences of $P$. radiatum (KM972998, KM973000, AY245708, and KM972999) with a high posterior probability and bootstrap (100/93) values.

The ND1 gene analysis (Fig. 3 B) showed that I. melis (KU516829) from Lithuania is related with I. hortensis (KR062182, AB189981, and AF025835).

\section{Discussion}

Morphology and measurements of $I$. melis from American mink and European polecat in Lithuania generally coincide with the descriptions of the species provided by Kostadinova and Gibson (2002). Flukes from our study from American mink $(6,329$ - 9,460 (7,864)) and European polecat $(5,734-9,251(7,644))$ are slightly longer compared to the descriptions of Kostadinova and Gibson (2002) $(4,564$ - 7,346 (5,577)) from European polecat, Dönges (1967) experimental material from ferret (Mustela putorius furo Linnaeus,

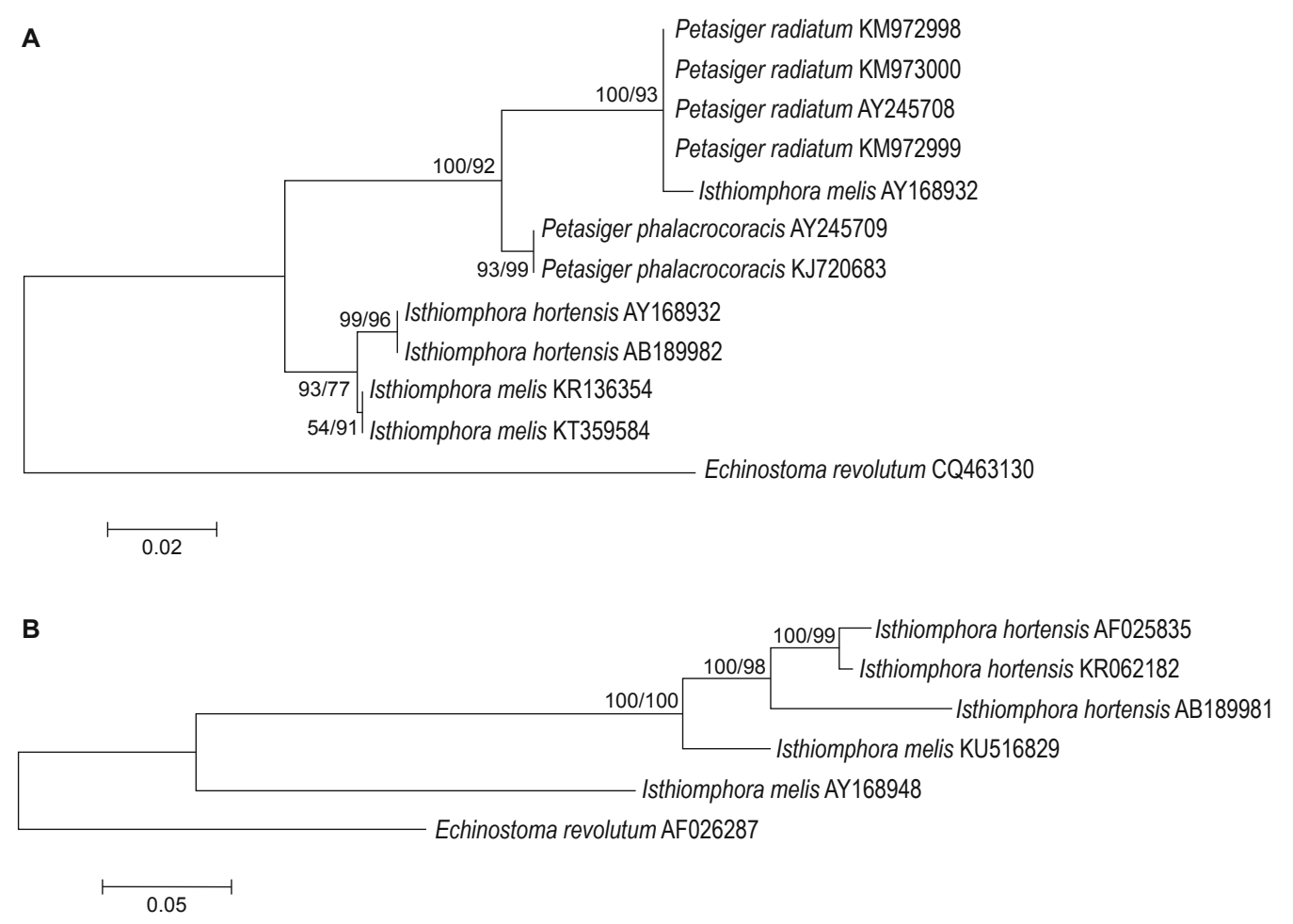

Fig. 3. Phylogenetic tree resulting from maximum likelihood (ML) and Bayesian inference (BI) analyses based on the ITS1 (A) and ND1 gene (B) dataset. Bayesian inference posterior probability values and Maximum Likelihood bootstrap values associated with the branches are shown as Bayesian inference/Maximum Likelihood. 
1758) $(5,320-6,380(5,790)$, and Hildebrand et al., (2015) from European badger $(5,950-7,725(6,821))$. Greater differences in fluke sizes can be observed in comparing Dönges (1967) experimental material from brown rats (Rattus norvegicus (Berkenhout, 1769)) $(2,090-5,710(3,580))$ and Hildebrand et al., (2015) material from striped field mouse (A. agrarius) $(1,075-4,100(2,625))$, European hedgehog (Erinaceus europaeus Linnaeus, 1758) (3,070 - 5,675 $(4,476))$, and American mink $(2,350-5,975(3,778))$. These differences in size can be explained by different age of flukes and influence of host species. The age of flukes from naturally infected hosts, as it is in our material, is unknown. Location of some organs appeared to be more variable in our material than in the description by Kostadinova and Gibson (2002). According to Kostadinova and Gibson (2002) follicles of vitellarium are distributed between level of ovary and posterior extremity. In our material follicles of vitellarium begin in two lateral fields between posterior level of ventral sucker and ovary. Such variability of anterior level of vitellarium follicles is mentioned by Dönges (1968) and is shown as statistically dependent on host species.

Since the aim of this study is identification and characterization of Isthmiophora flukes from American mink and European polecat in Lithuania, we will discuss distinctive features of the species with 27 head collar spines and problems in their identification. According to descriptions by Kostadinova and Gibson (2002), I. melis and I. hortensis have highly similar morphology. Their measurements are close and overlapping, so differences could be explained by age differences of flukes and different hosts. The main difference between I. melis and I. hortensis is the position of the cirrus sac. The cirrus sac in $I$. hortensis is located anterior to ventral sucker, while in I. melis the cirrus-sac reaches back dorsally from intestinal bifurcation to the middle of the ventral sucker dorsally, and occasionally to the posterior margin (Kostadinova \& Gibson, 2002). In our material, we also found specimens inclined to the side with the cirrus-sac located in anteriorly and laterally to the ventral sucker looking like 1. hortensis in figures 2 and 3 in Kostadinova and Gibson (2002). The differentiating feature of $I$. beaveri (Kostadinova \& Gibson 2002 ) is a more posterior position of the testes compared to that of closely resembling I. melis; according to the authors, the anterior testis of $I$. beaveri is equatorial and the post-testicular field is relatively short (30\% of the body length), whereas other species of the genus Isthmiophora with 27 head collar spines have the pre-equatorial anterior testis and a longer post-testicular field $(>30 \%$ of the body length). According to some descriptions and pictures of $I$. melis e.g. Dönges, 1967; Matskási, 1971; Kazlov, 1977; Ryzhikov et al., 1978; Sokolov et al., 2012, the anterior testis is equatorial or even post equatorial and the post-testicular field is relatively short. Dönges (1967) notes that the distance between the posterior testis and the end of the body in flukes from ferrets is on average twice as big as that in flukes from rats, where the length of adult flukes from rats and ferrets has the ratio of 0.62:1. I. melis specimens from striped field mouse described by Hildebrand et al., (2015) have a short post-testicular field in proportion to their body length
(26.6\%). Furthermore, as calculated for an average specimen from the original description by Beaver (1941), the post-testicular field is $45 \%$ of the body length; Beaver (1941) mentions that the location of the testes varies with the length of the worm. Having in mind the variability of the position of the testes and the relative length of the post-testicular field in I. melis, Sokolov et al., (2012) assumed that the validity of the $I$. beaveri species cannot be justified.

Dönges $(1967,1968,1970)$ showed in experimental infections that the host species influenced not only the absolute measurements, but also the relative size of organs. Adult worms in rats had considerable larger vegetative organs and smaller generative organs than those in ferrets (Dönges, 1967). Worms from pigs were the shortest, but relatively larger in width (Dönges, 1967, 1968). Adult flukes from different host species described by Dönges (1967, 1968,1970 ) were of different age, so effects of the parasite age and host may overlap. Host species also influenced the time of the start of egg production, its duration and fertility (Dönges, 1967, $1968,1970)$. These experiments enabled to synonymize echinostomatids Echinostoma spiculator Dujardin 1845 and Euparyphium suinum Ciurea 1921 with Isthmiophora melis (Schrank, 1788) (Dönges, 1967, 1968, 1970).

Comparison of the partial $18 \mathrm{~S}$ and $28 \mathrm{~S}$ rRNA genes sequences with the sequences in GenBank showed ambiguous results due to high similarity between $I$. melis and $I$. hortensis. These results did not permit identification of our material as I. melis or I. hortensis. Different regions of the rDNA repeat unit evolve at very different rates (Hillis \& Dixon, 1991), and because of slow evolution the obtained fragments of $18 \mathrm{~S}$ and $28 \mathrm{~S}$ rRNA genes is unsuitable for differentiation of closely related species.

The partial sequences of ITS1-5.8S-ITS2 region (KR136354) were more useful showing $100 \%$ similarity with I. melis (KT359584) from Poland, but only $95 \%$ matches with I. melis (AY168932) from the United Kingdom. Furthermore, the subsequence of ITS1 has even less similarity, only $92 \%$ similarity with the sequence of $I$. melis (AY168932) originated from larval stages (redia and cercaria), which were collected from molluscs Planorbis sp. (Kostadinova et al., 2003) was identified. However, other authors argue that the intermediate hosts of $I$. melis are molluscs of the Lymnaeidae family or great pond snail (L. stagnalis) (Kostadinova \& Gibson, 2002; Radev et al., 2009). A phylogenetic analysis and comparison of the I. melis sequence (AY168932) (collected from molluscs) with other sequences shows its close similarity to sequences of P. radiatum (KM972998, KM973000, AY245708, and KM972999). A close similarity between the I. melis sequence (AY168932) and $P$. radiatum sequences has already been identified by Molnár et al., (2015). The intermediate hosts of $P$. radiatum are molluscs of the genus Planorbis (Našincová et al., 1993). Also, it is difficult to distinguish the larvae stages of $I$. melis from other similar species, especially from $P$. radiatum (Kiselienè, 1970; Grabda-Kazubska \& Laskowski, 1996) due to their similar structure. The fluke species for AY168932 sequence in GenBank is likely wrongly annotated. Different parts of the sequence KR136354 were of different value 
for species identification: the most valuable were sequences of ITS1 and the least valuable was the 5.8S rRNA gene sequence and the ITS2 fragment. The 5.8S rRNA gene is considered to have high degree of conservation and is too short to be informative in phylogenies across large time scales (Hillis \& Dixon, 1991, Hershkovitz \& Lewis, 1996; Coleman, 2003).

The ND1 gene sequence of flukes from mustelids in Lithuania (KU516829) shared the biggest similarity with sequences of $I$. hortensis from China (KR062182) and Korea (AF025835), yet 90$91 \%$ is so much lower than the corresponding ITS1 sequences. This corresponds with the data by Morgan and Blair (1998) that the sequence divergence among 37 collar-spine Echinostoma was comparatively lower in ITS, higher in cytochrome c oxidase I gene (COI) and the highest in ND1. The same pattern is also observed for other platyhelminth parasites (Vilas et al., 2005). Notably, as in case of ITS1, the similarity of the KU516829 sequence with the AY168948 sequence of $I$. melis detected in molluscs (Planorbis $\mathrm{sp}$.) in the United Kingdom was low. Furthermore, we can note that the divergence of $\mathrm{COI}$ sequences of $I$. melis and I. hortensis is intermediate compared with ITS1 and ND1. COI sequences of $I$. melis from Poland (KT359580, KT359581) have 93 - $95 \%$ homology with sequences of $I$. hortensis from Japan (AB189980), Korea (AF025826, AF096227), and China (KR062182).

\section{Conclusion}

Based on morphological characteristics and the DNA sequence data we conclude that the flukes of the Isthmiophora genus in $M$. putorius and $N$. vison from Lithuania represent $I$. melis species. According to the ITS1 and ND1 gene sequences the closest to $I$. melis is I. hortensis.

\section{Acknowledgments}

This research was financed by the Research Council of Lithuania (grant No. LEK-14/2012).

\section{References}

Beaver, P.C. (1941): Studies on the life history of Euparyphium melis (Trematoda: Echinostomatidae). J. Parasitol., 27(1): 35 - 44. DOI: $10.2307 / 3272884$

Coleman, A.W. (2003): ITS2 is a double-edged tool for eukaryote evolutionary comparisons. Trends Genet., 19(7): 370 - 375. DOI: 10.1016/S0168-9525(03)00118-5

DORNEY, R.S., LAUERMAN, L.H. (1969): A helminthological survey of wild mink in Wisconsin. Bull. Wildl. Disease Assoc., 5(1): 35 - 36. DOI: 10.7589/0090-3558-5.1.35

DöngES, J. (1964): A local, facultative Echinostomatide (Trematoda) type human pathogen and infection course in humans. Z. Parasitenkd., 25(1): 3. DOI: 10.1007_bf00348641 (In German)

DönGES, J. (1967): The Modifying Effect of the Final Host on the
Development of the Intestinal Fluke Isthmiophora melis (Schrank, 1788). A Rehabilitation of the Genus Isthmiophora Lühe, 1909 (Trematoda, Echinostomatidae). Z. Parasitenkd., 29(1): 1 - 14. DOI: 10.1007/BF00328835 (In German)

Dönges, J. (1968): The Modifying Effect of the Final Host on the Development of the Intestinal Fluke Isthmiophora melis (Schrank, 1788) II. Euparyphium suinum Ciurea, 1921, a Synonym of Isthmiophora melis. Z. Parasitenkd., 30(3): 179 - 184. (In German.) DOI: 10.1007/BF00259628

DönGES J. 1970: The Modifying Effect of the Final Host on the Development of the Intestinal Fluke Isthmiophora melis (Schrank, 1788) III. The Development in the Brown Rat (Rattus norvegicus), a Natural Final Host. Z. Parasitenkd., 35(2): 169 - 172. DOI: 10.1007/BF00259994 (In German)

GRABDA-KaZUBSKA, B., LASKOWSKI, Z. (1996): On the morphology and chaetotaxy of rediae and cercariae of Isthmiophora melis (Schrank, 1788) (Trematoda, Echinostomatidae). Acta Parasitol., 41(1): 7 - 12

GUPTA, S.P. (1962): A redescription of Euparyphium melis (Schrank, 1788) Dietz, 1909 and Echinostoma revolution (Froelich, 1802) Looss, 1899 parasitic in the intestine of mink (Mustela vison) and muskrat (Ondatra zibethica) from Canada. Indian J. Hel., 14(2): $77-85$

Hershrovitz, M.A., LewIS, L.A. (1996): Deep-level diagnostic value of the rDNA-ITS region. Mol. Biol. Evol., 13(9): 1276 - 1295. DOI: 10.1093/oxfordjournals.molbev.a025693

Hildebrand, J., Adamczyk, M., LAsKowski, Z., Zaleśny, G. (2015): Host-dependent morphology of Isthmiophora melis (Schrank, 1788) Luhe, 1909 (Digenea, Echinostomatinae) - morphological variation vs. molecular stability. Parasit. Vectors., 8: 481. DOI: 10.1186/s13071-015-1095-8

HilıIs, D.M., Dıxon, M.T. (1991): Ribosomal DNA - molecular evolution and phylogenetic inference. Q. Rev. Biol., 66(4): 411 - 453. DOI: 10.1086/417338

IVASHKIn, V.M., KontrimavičIUS, V.N., Nazarova, N.S. (1971): Methods of collaction and study of terrestrian mammal helminthes. Nauka, Moscow, 124 pp. (In Russian)

KaZlauskas, J., Prūsaité, J. (1976): Helminths of carnivores in Lithuania. Acta Parasitol. Lituan., 12: 33 - 40. (In Russian)

KISELIENÉ, V. (1966): On the helminthological evaluation of water basins used for the growth of domestic water fowl. Acta Parasitol. Lituan., 6: $55-66$

KISELIENĖ, V. (1970): The biological characteristics of Paryphostomum radiatum (Dujardin, (Echinostomatidae). Acta Parasitol. Lithuan., 10: 31 - 40. (In Russian)

KLUPIEC, P. (2001): Helmith-fauna of polecats (Mustela putorius L.) in their Northwest German distribution areas. Vet. med. diss., 94 pp. (In German)

KonTRIMAVICHUS, V.L. (1966): The helminth fauna of American mink acclimatized in the Khabarovsk Territory. In: Yanushevich, A.I. (Eds) Acclimatization of animals in the U.S.S.R., pp. $241-242$

Kostadinova, A., Gibson, D.I. (2002): Isthmiophora Lühe, 1909 and 
Euparyphium Dietz, 1909 (Digenea: Echinostomatidae) re-defined, with comments on their nominal species. Syst. Parasitol., 52(3): 205 - 217. DOI: 10.1023/A:1015789703396

Kostadinova, A., Herniou, E.A., Barrett, J., Littlewood, D.T.J. (2003): Phylogenetic relationships of Echinostoma Rudolphi, 1809 (Digenea: Echinostomatidae) and related genera re-assessed via DNA and morphological analyses. Syst. Parasitol., 54(3): 159 176. DOI: $10.1023 / \mathrm{A}: 1022681123340$

Kozlov, D.P. (1977): Key to Helminths of Carnivorous Mammals of the USSR. Nauka, Moscow, 276 pp. (In Russian)

LAW, R., Kennedy, A. (1932): Parasites of furbearing animals. Bull. Dept. Game and Fisheries, Ontario 4: 1 - 30.

LITTLEWOOD, D.T.J., OLSON, P.D. (2001): Small subunit rDNA and the Platyhelminthes: Signal, noise, conflict and compromise. In: D.T.J. LITTLEWOOd, D.T.J., Bray, R.A. (Eds.) Interrelationships of the Platyhelminthes, Taylor and Francis Publishing, London, pp. 62 - 278. MATSKÁSI, I. (1971): The Trematode Fauna of Rodents and Insectivora (Mammalia) in Hungary. I. Parasit. Hung., 4: 125 - 136 Molnár, K., Gibson, D.I., Cech, G., Papp, M., DeÁk-Paulus, P., JuHÁSz, L., TótH, N., SzÉKELY, C. (2015): The occurrence of metacercariae of Petasiger (Digenea: Echinostomatidae) in an unusual site, within the lateral line scales of cyprinid fishes. Folia Parasitol., 62: 017. DOI: 10.14411/fp.2015.017

Morgan, J.A.T., BLAIR, D. (1995): Nuclear rDNA ITS sequence variation in the trematode genus Echinostoma: An aid to establishing relationships within the 37-collar-spine group. Parasitology, 111(5): 609 - 615. DOI: 10.1017/S003118200007709X

Morgan, J.A.T., BLAIR, D. (1998): Relative merits of nuclear ribosomal internal transcribed spacers and mitochondrial CO1 and ND1 genes for distinguishing among Echinostoma species (Trematoda). Parasitology, 116(3): 289 - 297. DOI: $10.1017 /$ S0031182097002217

Našıncová, V., Scholz, T., Moravec, F. (1993): The life cycle of Paryphostomum radiatum (Dujardin, 1845) (Trematoda: Echinostomatidae), a parasite of cormorants. Folia Parasitol., 40(3): 193 $-201$

Nugaraité, D., Mažeika, V., Paulauskas, A. (2014): Helminths of mustelids (Mustelidae) in Lithuania. Biologija, 60(3): 117 - 125. DOI: 10.6001/biologija.v60i3.2970

Olson, P.D., CRibB, T.H., TKach, V.V., Bray, R.A., LitTlewood, D.T.J. (2003): Phylogeny and classification of the Digenea (Platyhelminthes: Trematoda). Int. J. Parasitol., 33(7): 733 - 755. DOI: 10.1016/S0020-7519(03)00049-3

Radev, V., Kanev, I., Khrusanov, D., Fried, B. (2009): Reexamination of the life cycle of Isthmiophora melis (Trematoda: Echinostomatidae) on material from southeast Europe. Parazitologiia 43(6): 445 - 453. (In Russian)

Ryzhikov, K.M., GvozdeV, E.V., TokobaeV, M.M., Shaldybin, L.S., Matsaberidze, G.V., Merkusheva, I.V., NadtochiJ, E.V., Khokhlova, I.G., SHARPILO, L.D. (1978): Key to helminths of rodents of the fauna of the USSR: tapeworms and flukes. Nauka, USSR, pp. 232. (In Russian)
Ronquist, F., Teslenko, M., Van Der Mark, P., Ayres, D.L., Darling, A., Hohna, S., Larget, B., Liu, L., Suchard, M.A., Huelsenbeck, J.P. (2012): MrBayes 3.2: Efficient bayesian phylogenetic inference and model choice across a large model space. Syst. Biol., 61(3): 539 - 542. DOI: 10.1093/sysbio/sys029

SATO, H., SuzuKI, K. (2006): Gastrointestinal helminths of feral raccoons (Procyon lotor) in Wakayama Prefecture, Japan. J. Vet. Med. Sci., 68(4): 311 - 318. DOI: 10.1292/jvms.68.311

Shimalov, V.V., Shimalov, V.T. (2001): Helminth fauna of the American mink (Mustela vison Schreber, 1777) in Belorussian Polesie. Parasitol. Res., 87(10): 886 - 887. DOI: 10.1007/s004360100461 Shimalov, V.V., Shimalov, V.T. (2002): Helminth fauna of the European polecat (Mustela putorius Linnaeus, 1758) in Belorussian Polesie. Parasitol. Res., 88(3): 259 - 260. DOI: 10.1007/s00436001-0521-3

Sokolov, S.G., Protasova, E.N., Reshetnikov, A.N., Shed'ko, M.B. (2012): Parasites of introduced rotan Perccottus glenii (Actinopterygii: Odontobutidae) from water bodies of European Russia. Uspekhi Sovremennoy Biologii. 132: 477 - 492 (In Russian)

Soltys, A. (1962): Helminth parasites of Mustelidae of the Lublin Palatinate. Acta Parasitol. Pol., 10(1/11): 73 - 76.

SugÁR, L., MATSKÁsI, I. (1978): Occurrence of Isthmiophora melis (Schrank, 1788) and Alaria alata (Goeze, 1782) in wild carnivora in Hungary. Parasit. Hung., 11: 142

Tamura, K., Stecher, G., Peterson, D., Filipski, A., Kumar, S. (2013): MEGA6: Molecular Evolutionary Genetics Analysis version 6.0. Mol. Biol. Evol., 30(12): 2725 - 2729. DOl: 10.1093/molbev/mst197 TKaCH, V., PaWloWski, J. (1999): A new method of DNA extraction from the ethanol-fixed parasitic worms. Acta Parasitol., 44(2): 147 $-148$

TKaCh, V., PaWlowsKI, J., MariauX, J. (2000): Phylogenetic analysis of the suborder Plagiorchiata (Platyhelminthes, Digenea) based on partial IsrDNA sequences. Int. J. Parasitol., 30(1): 83 - 93. DOI: 10.1016/S0020-7519(99)00163-0

TKach, V.V., Kudlal, O., Kostadinova, A. (2016): Molecular phylogeny and systematics of the Echinostomatoidea Looss, 1899 (Platyhelminthes: Digenea). Int. J Parasitol., 46(3): 171 - 185. DOI: 10.1016/j.jpara.2015.11.001

Thompson, J.D., HIGgins, D.G., GiBson, T.J. (1994): CLUSTAL W: improving the sensitivity of progressive multiple sequence alignment through sequence weighting, position-specific gap penalties and weight matrix choice. Nucleic Acids Res., 22(22): 4673 - 4680. DOI: 10.1093/nar/22.22.4673

VILAS, R., CRISCIONE, C.D., Blouin, M.S. (2005): A comparison between mitochondrial DNA and the ribosomal internal transcribed regions in prospecting for cryptic species of platyhelminth parasites. Parasitology. 131(6): 839 - 846. DOI: 10.1017/ S0031182005008437

Zschille, J., Heidecke, D., StubBe, M. (2004): Distribution and ecology of feral American mink Mustela vison Schreber, 1777 (Carnivora, Mustelidae) in Saxony-Anhalt (Germany). Hercynia, 37(1): $103-126$ 